\title{
The Tourism Product Element of Semarang Old City Area BaSed ON AtTractive Urban Heritage APPROACH
}

\author{
Pengembangan Elemen Produk Wisata \\ DI KaWASAn Kota Lama SEMarang \\ Dengan Pendekatan Attractive Urban Heritage
}

\author{
Cinthyaningtyas Meytasari ${ }^{1^{*}}$, Endah Tisnawati ${ }^{2}$ \\ Program Studi Arsitektur, Fakultas Sains dan Teknologi, Universitas Teknologi Yogyakarta ${ }^{1}$ \\ c.meytasari@uty.ac.id* \\ Program Studi Arsitektur, Fakultas Sains dan Teknologi, Universitas Teknologi Yogyakarta ${ }^{2}$
}

\begin{abstract}
The Old Town Semarang is a historical asset of the former Dutch East Indies colonial that is rich in tourism and science potential. The Old Town Semarang as a historical tourist attraction, divided into aspects of products, physical environment and the driving force of tourism elements. Each aspect has been possessed by The Old Town Semarang, but needs development in order to realize the Old Town Semarang as study center and attractive urban heritage tourism through the development of heritage products, and supported by elements of driving elements of tourism, such as government, private and community, through product studies and the driving force tourism, so that the Old Town Semarang can play a role in science regional tourism, even national, with the needs, tour / tour guides, and community, against the Old Town Semarang. Although in fact there are several inhibiting factors in realizing the Old City of Semarang as a historical tourist attraction.
\end{abstract}

Keywords: tourism product elements, study center, attractive urban heritage.

\section{LATAR BELAKANG}

Semarang memiliki peran yang sangat penting dalam peningkatan perekonomian di Jawa Tengah. Berbagai kelengkapan infrastruktur fisik seperti pelabuhan, jaringan jalan dan sistem transportasi darat dan laut, memberikan nilai strategis sebagai kota transit regional di Jawa Tengah sejak jaman penjajahan hingga saat ini. Demikian juga dengan posisi strategis secara geografis, dimana Semarang menjadi penghubung dengan wilayah-wilayah lain di luar Pulau Jawa, melalui sistem perdagangan dan jasa baik yang melewati jalur laut, darat, maupun udara.

Kondisi strategis Kota Semarang telah memberikan peluang yang sangat penting bagi pengembangan aktifitas pariwisata. Pola-pola pengembangan pariwisata juga sejalan dengan RIPP (Rencana Induk Pengembangan Pariwisata), yang dalam strategi internalnya berupa optimalisasi potensi kepariwisataan bagi investasi daerah. Optimalisasi peran kota-kota pelayanan utama dan Kota Semarang, telah menjadi fokus pengembangan sesuai dengan RIPP Kota Semarang. Semarang dengan kota lamanya telah direncanakan untuk dikembangkan dan dikelola sebagai kawasan wisata sejarah (heritage tourism).

Lokasi Kota Lama Semarang berada di tempat strategis, Kota Lama Semarang menjadi satu kawasan dengan infrastruktur penting yaitu dengan keberadaan Stasiun kereta api Tawang, yang juga merupakan stasiun dengan bangunan heritage. Letak kawasan ini juga tidak jauh 
dengan pelabuhan besar yaitu Pelabuhan Tanjung Mas. Keberadaan infrastrukturinfrastruktur tersebut membuat Kota Lama Semarang sebenarnya berada dalam sebuah sistem yang semestinya tidak terlepas dengan perkembangan pariwisata di daerah lain. Sistem tersebut diantaranya adalah street, square, elemen sirkulasi, area parkir, jalur pedestrian, dan adanya kegiatan di dalamnya. Dalam konteks ini, aktifitas pariwisata, elemen pencapaian, kemenarikan, kelengkapan dan street furniture menjadi sangat penting sebagai pembentuk Kota Lama yang berpotensi mendukung pariwisata.

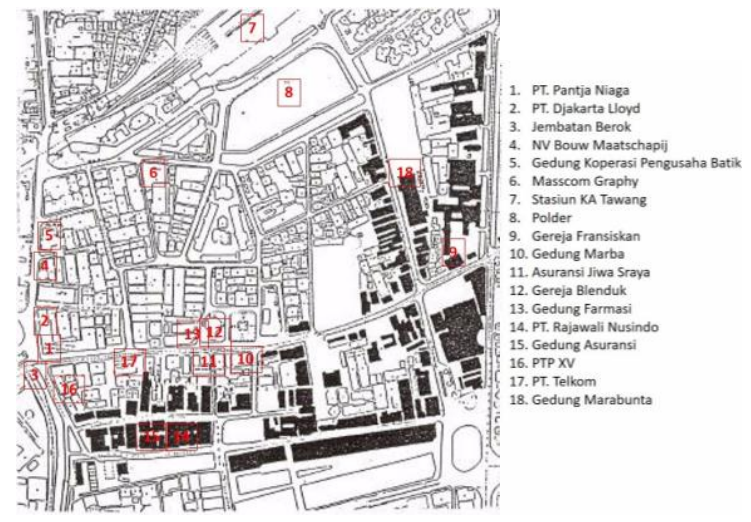

Gambar 1. Peta Sebaran urban heritage utama Kota Semarang, Jawa Tengah

Sumber : DPU Kota Semarang, 2017, dengan beberapa penyesuaian, 2018

Kota Lama Semarang sebagai salah satu peninggalan sejarah, menurut Attoe (1978) dalam Hollander (1980), memiliki kriteriakriteria dalam kerangka pengembangan menjadi tujuan wisata sejarah kota (urban heritage tourism), yaitu: estetika, kejamakan, kelangkaan, peranan sejarah, dan keberadaannya mampu memperkuat kawasan. Disisi lain, penekanan juga tampak pada fungsi tata ruang dari Kota Lama Semarang, yang mempertimbangkan distribusi geografis dari sumber daya atau objek wisata, jaringan sarana dan prasarana, fasilitas dan pelayanan.

Heritage sendiri sebagai sebuah peninggalan budaya, yang menurut Bowes (1989), dalam Yuliasari (2017), tidak hanya berupa situs peninggalan sejarah tetapi juga meliputi suatu kawasan dan elemen-elemen yang terdapat di dalamnya. Dalam kenyataanya, Larkham (1995) mengemukakan tiga hal penting dalam perencanaan heritage, yaitu preservasi, konservasi dan eksploitasi. Konservasi dapat diartikan sebagai konsep proses pengelolaan suatu tempat agar makna kultural yang terkandung terpelihara dengan baik (Inskeep, 1991). Menurut Burra Charter (Anonim, 1981), konservasi mencakup preservasi, restorasi, rekonstruksi, adaptasi dan revitalisasi.

Satu hal yang belum diperhitungkan di Kota Lama Semarang adalah potensinya sebagai pusat studi mengenai tata kota dengan tipikal ceruk/basin, dimana kota jenis ini mempunyai permasalahan yang unik, sehingga tata kota, tata kelola kota, maupun arsitekturnya mempunyai ciri yang khas, yang tidak dimiliki kota lain.

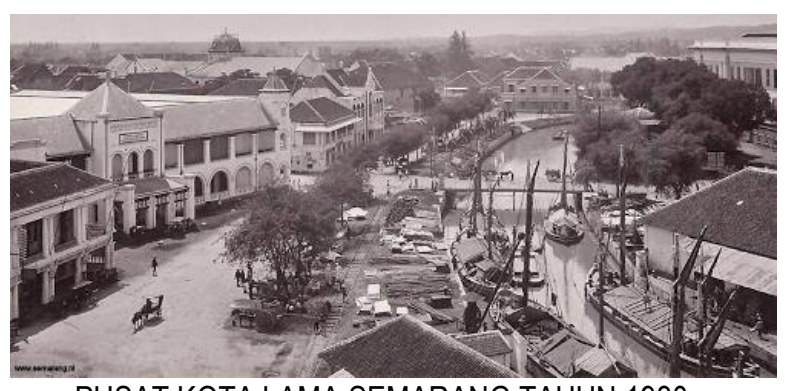

PUSAT KOTA LAMA SEMARANG TAHUN 1930

Sumber : http://seputarsemarang.com/wallpaperfoto-semarang-tempo-dulu/, diakses 24 Maret 2018

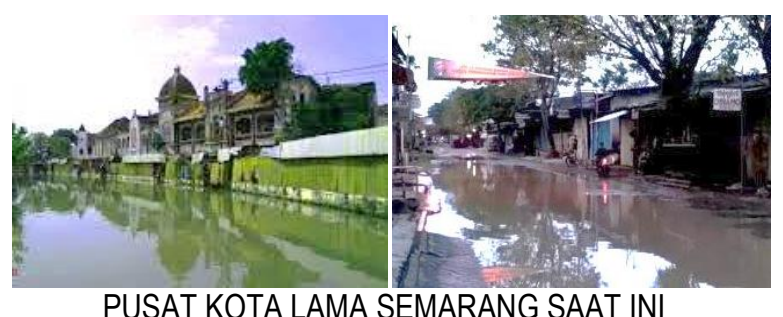

Sumber : https://sejarahsemarang.wordpress.com/ banjir/, diakses 24 Maret 2018

Gambar 2. Kondisi Kota Lama Semarang tempo dulu (1930) dan saat ini (2018)

Kota Lama Semarang sejatinya adalah kota yang seakan-akan berdiri sendiri karena dahulu merupakan kota benteng yang dikelilingi oleh kanal yang terhubung dengan Kali Semarang. Dahulu kanal-kanal ini merupakan nadi perekonomian karena kapal-kapal dagang dapat merapat hingga ke area pergudangan di Kota Lama Semarang. Namun saat ini kanal-kanal tersebut sudah tidak bisa difungsikan seperti dahulu karena berbagai sebab, beberapa diantaranya munculnya permukiman liar di tepiannya, ditutupnya kanal dengan beton, dsb (Gambar 2). Kanal-kanal ini dibuat selain 
(dulunya) fungsi keamanan sebagai kota benteng, juga karena Kota Lama Semarang sebenarnya merupakan Tidal Gate (pintu pasang surut di muara sungai), dimana ketika air pasang naik akan memberi dampak pada kota (banjir rob).

\section{LANDASAN TEORI}

Kota Lama Semarang sarat dengan sumber daya berupa bangunan-bangunan cagar budaya zaman kolonial yang masih dalam kondisi sangat baik. Selama ini potensi yang sudah digarap barulah sebatas konservasi dengan memanfaatkan bangunan-bangunan heritage tersebut walaupun masih dalam tataran 'dangkal', yaitu pemugaran dan memberi fungsi baru pada bangunan tersebut. Potensi lain sebagai pusat studi belum digarap sama sekali. Kota Lama Semarang sebagai Pusat Studi masuk ke dalam Wisata Edukasi, yang untuk mewujudkannya memerlukan motor melalui elemen-elemen produk yang dikembangkan dan juga elemen penggerak yang menunjang peningkatan pariwisata di Kota Lama Semarang sebagai urban heritage tourism. Menurut Kotler (1996), elemen produk terbagi dalam 4 (empat) tingkatan, yaitu: (1) core product, (2) facilitating product, (3) supporting product, (4) augmented product. Masing-masing dari tingkatan produk tersebut dapat diukur dengan 3 (tiga) hal pokok sebagai parameternya, yaitu: kualitas produk, penampilan produk, dan inovasi karakter produk.

Wisata edukasi cenderung nampak membosankan, sehingga perlu pendekatan atraktif supaya Kota Lama sebagai Basin City Study Center bisa dinikmati dan dimanfaatkan oleh semua lapisan, tidak hanya ilmuwan, tetapi juga kalangan pelajar dan masyarakat umum. Salah satu penjabaran atraktif adalah melalui metoda metafora. Geoffrey Broadbent dalam bukunya Design in Architecture, menjelaskan bahwa metafora adalah menerjemahan bentuk dari sesuatu. Menurut Antoniades (1990), ada tiga kategori dari metafora:

1. Intangible Metaphors adalah metafora yang tidak dapat diraba (konsep, ide, kondisi manusia/kualitas-kualitas khusus seperti individual, naturalistis, komunitas, tradisi, dan budaya)
2. Tangible Metaphors adalah metafora yang dapat diraba dan dirasakan, dari suatu karakter visual atau material.

3. Combined Metaphors yaitu penggabungan antara keduanya, dimana secara konsep dan visual saling mengisi sebagai unsur-unsur awal dan visualisasi sebagai pernyataan untuk mendapatkan kebaikan kualitas dan dasar.

Tampilan atraktif berkaitan dengan makna arsitektural, yang sangat berpengaruh pada emosi (psikologi) pelaku/pengamat (Laurens, 2004, dalam Hess, 2007). Masih menurut Laurens (2004), dalam Hess (2007), makna Arsitektural mencakup 2 (dua) makna dasar, yaitu makna representasional dan makna responsif. Berikut penjelasan dari makna tersebut:

1. Makna Representasional. Terdiri dari 2 (dua) jenis, yaitu makna presentasional (berupa ikon) dan makna referensional (simbol terhadap obyek atau peristiwa tertentu). Jadi makna representasional berkaitan dengan bentuk, tekstur, warna, status, ukuran, dan atribut lain.

2. Makna responsif. Terdiri dari 3 (tiga) jenis, yaitu makna afektif (perasaan dan emosi seseorang ketika melihat suatu bentuk bangunan. Respon ini didasari oleh pengalaman dan budaya pengguna), makna evaluatif (penghayatan seseorang terhadap representasi dan emosi seketika berdasarkan kompetensinya), makna preskriptif (penghayatan seseorang untuk melakukan sesuatu setelah melihat dan mengevaluasinya). Jadi makna resposif adalah sistem komunikasi melalui komponen bangunan.

Kualitas fisik dari tampilan atraktif kawasan sebagai produk wisata Urban Heritage menurut Cullen (1961) dalam Nuryanti (1996) dapat diukur dengan parameter sebagai berikut:

1. Optik (optic). Pemandangan kota sering diungkapkan dalam suatu seri dari kejutan (jerk)/pengungkapan rahasia (revelation). Seri pemandangan ini dinamakan sebagai serial vision (concerning optics).

2. Tempat (place). Berkenaan dengan reaksi pengamat terhadap posisi pengamat dalam lingkungannya, sehingga diperoleh situasi yang dramatis.

3. Isi (content). Berkenaan dengan struktur elemen kota (fabric of town), seperti: skala, 
tekstur, karakter, personalitas, dan keunikan.

\section{RUMUSAN MASALAH}

Ada beberapa permasalahan yang perlu diselesaikan agar program pengembangannya dapat dilaksanakan dengan baik. Diantaranya adalah:

a. Bagaimana meningkatkan kualitas dan kuantitas elemen-elemen produk Kota Lama Semarang berbasis pendekatan atraktif?

b. Bagaimana merumuskan arahan penataan kawasan yang tepat di Kota Lama Semarang dengan elemen produk dan penggerak wisatanya?

Tujuan penulisan artikel ilmiah ini adalah untuk mengidentifikasi cara mewujudkan/ memajukan kawasan Kota Lama Semarang sebagai Basin City Study Center sebagai perwujudan wisata edukasi, melalui pengembangan produk attractive heritage city, dan didukung oleh elemen elemen penggerak pariwisata, seperti aparat pemerintah, swasta, maupun masyarakat setempat, melalui kajian produk, elemen pengerak pariwisata, dan pemaknaan arsitektural, sehingga Kota Lama Semarang mampu berperan dalam kepariwisataan daerah, bahkan nasional, dengan memenuhi permintaan kebutuhan pariwisata, tour operator/tour guide, serta masyarakat, terhadap Kota Lama Semarang.

Manfaat penulisan ini artikel ilmiah adalah guna mendukung upaya pengembangan kawasan wisata Kota Semarang, pelestarian sejarah dan budaya, khususnya di kawasan Kota Lama Semarang dan menjadi masukan bagi pengembangan seluruh komponen dari elemen penggerak wisata dalam mengembangkan dan melestarikan Kota Lama Semarang agar tetap berkelanjutan, yang kemudian dapat menjadi referensi bagi Pemerintah Daerah dalam pengembangan pariwisata dan pelestarian budaya Kota Semarang.

\section{METODE PENELITIAN}

Metode yang digunakan dalam penelitian ini adalah metode deskriptif kualitatif rasionalistik Yaitu untuk menggambarkan keadaan objek dan persoalannya. Metode ini dipergunakan dengan cara mengkaji produk wisata Kota Lama Semarang sebagai pusat studi kota ceruk (basin city) beserta elemen-elemen penggerak pariwisatanya. Upaya peninjauan dilakukan terhadap beberapa lingkup bekas (eks.) bangunan-bangunan kuno yang masih bercirikan bangunan kolonial, jaringan infrastruktur jalan, sistem dan fasilitas akomodasi, jaringan kanal-kanal, bekas benteng, serta kondisi lingkungan secara umum. Sisi pandang dari kacamata pariwisata diarahkan kepada elemen produk wisata. Dikombinasikan dengan aspek-aspek khusus dari sisi arsitektur yaitu kualitas fisik kawasan (atraktif) melalui parameter optic, place, content.

Untuk penelitian terhadap sistem aktivitas kawasan baik itu di dalam dan di luar ruang dilakukan secara global dalam periode waktu tertentu. Sistem aktivitas ini meliputi kegiatan masyarakat khususnya dalam bidang pariwisata, yang mencakup ekonomi, sosial dan budaya.

Penelitian terbagi atas beberapa tahapan, diantaranya adalah :

1. Tahap Persiapan. Di tahap ini, yang dilakukan adalah memantapkan kerangka penelitian dan mempersiapkan kegiatan pengumpulan data.

2. Tahap Pengumpulan data. Pada tahap ini dilakukan kegiatan pengambilan data dengan melakukan kegiatan wawancara dan pengamatan lapangan. Wawancara dilakukan kepada wisatawan, pelaku pariwisata terkait, masyarakat dan pemerintah. Wawancara kepada wisatawan bertujuan untuk mengetahui demand, dan ekspektasi terhadap kawasan, yang menyang-kut atraksi, amenitas, aksesibilitas, dan fasilitas wisata lainnya. Juga untuk mengetahui sejauh mana masyarakat/wisatawan mengetahui potensi Kota Lama sebagai Basin City. Kegiatan wawancara kepada Pemerintah (instansi terkait) bertujuan untuk mengetahui ekspektasi dan motivasi pemerintah dalam mengembangkan kawasan, terutama yang menyangkut produk pariwisata. Kegiatan wawancara kepada tour operator bertujuan untuk mengetahui demand dan ekspektasi terhadap kawasan (termasuk di dalamnya produk-produk pariwisata Kota Lama Semarang). Sementara, wawancara kepada masyarakat bertujuan untuk mengetahui 
demand dan ekspektasi, motivasi masyarakat, serta tingkat kesiapan masyarakat terhadap rencana pengembangan kawasan sebagai urban heritage tourism.

3. Tahap Analisis Data. Data dari hasil observasi dan identifikasi yang berupa data fisik dan non fisik kawasan kemudian dilakukan analisis. Hasil analisis kemudian harus diselesaikan dalam arahan penataan Kota Wisata.

4. Tahap Penyimpulan Hasil Penelitian. Pada tahapan ini dilakukan kajian antar tema dan kategori yang muncul dari tahap analisis, tahapan ini diharapkan dapat memberikan informasi tentang arahan yang tepat di Kampung Wisata Batik Kauman Surakarta.

\section{HASIL DAN PEMBAHASAN}

\subsection{Kota Semarang sebagai Basin City}

Topografi Kota Semarang berbentuk kemiringan. $65,22 \%$ dari wilayah kota Semarang berupa pantai dengan kemiringan $25 \%$, dan $37,78 \%$ nya merupakan daerah perbukitan dengan kemiringan 15-40\%. Kondisi lereng tanah Kota Semarang dibagi menjadi 4 jenis kelerengan yaitu lereng I (0$2 \%)$, lereng II (2-5\%), lereng III (15-40\%) dan lereng IV (> 50\%).
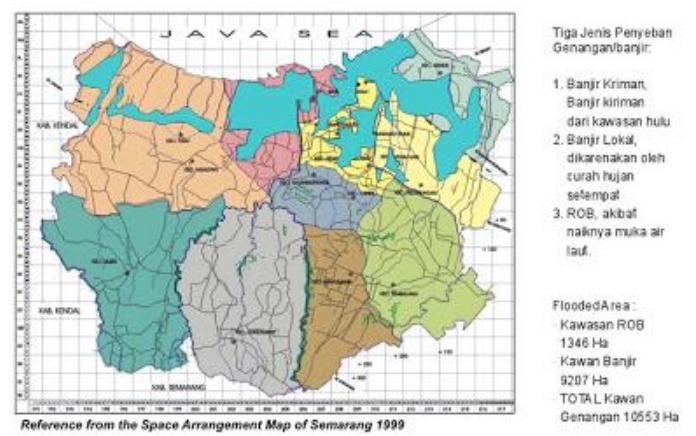

Gambar 3. Kawasan Genangan Kota Semarang Sumber: DPU Kota Semarang, 2017

Dari Gambar 3. terdata bahwa 1346 ha tergenang akibat rob, dan 9207 ha genangan akibat hujan dan tidak lancarnya drainase kota. Kota Lama Semarang merupakan kawasan yang terdampak keduanya. Hal ini akibat dari Kota Lama Semarang masuk dalam dataran rendah yang berdekatan dengan pantai, sehingga mempunyai kelerengan kurang dari 2\%. Hal ini menyebabkan saat musim hujan akan selalu mengalami banjir dan saat pasang air laut akan mengalami rob. Kota Lama Semarang dulunya adalah kawasan yang merupakan pusat pemerintahan Belanda, sehingga sekelilingnya dilindungi oleh benteng (dinamai Vijfhoek). Namun benteng tersebut pada akhirnya dirubuhkan karena Belanda memperluas wilayah hingga keluar area benteng.

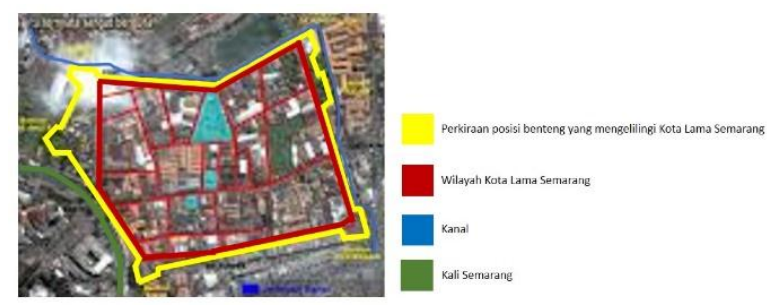

Gambar 4. Benteng dan

Wilayah Kota Lama Semarang Sumber: DPU Kota Semarang, 2017

Dari hasil survey dan penelitian dokumen gambar bangunan yang ada di Kota Lama Semarang (dan sekitarnya), bangunanbangunan tersebut rata-rata mempunyai basement yang digunakan untuk menampung banjir rob. Selain itu, Belanda juga membangun kanal-kanal yang sangat berguna untuk aliran air, yang terhubung dengan Kali Semarang. Selain kanal, Belanda juga banyak membangun gorong-gorong bawah tanah dengan ukuran yang besar. Namun goronggorong tersebut saat ini keberadaannya sudah banyak yang hilang, berganti dengan bangunan baru, atau ada juga yang ditimbun/ditutup. Metode yang dilakukan Belanda ini merupakan metode yang sudah ratusan tahun dipakai di Belanda karena Belanda mempunyai karakteristik topografi yang mirip dengan kota Semarang, sehingga Kota Lama Semarang sering disebut sebagai Little Netherland/ Outstadt oleh orang Belanda. Belanda mempunyai metode khusus dalam menangani banjir dan rob, yang berpengaruh pada tata letak keruangan wilayah (zonasi), karakter bangunan 
yang berbeda dengan bangunan Belanda yang berada di luar Semarang bawah, dan infrastruktur kota. Dan semua itu bisa dilihat dan dipelajari di satu tempat, yaitu di Kota Lama Semarang.

\subsection{Kota Lama Semarang sebagai Produk Pariwisata}

Pengembangan Kota Lama Semarang sebagai produk pariwisata tidak lepas dari pembahasan dari sisi aspek produk dan Aspek Elemen Penggerak Pariwisata. Berikut analisis dari kedua aspek tersebut.

\section{a. Aspek Produk}

Kota Lama sudah merupakan kawasan yang terseleksi sebagai kawasan heritage, karena empat kriteria sudah ada di Kota Lama, yaitu estetika, kejamakan, peranan sejarah, dan memperkuat kawasan, sehingga keberadaannya mampu memperkenalkan Semarang sebagai salah satu kota yang mempunyai warisan sejarah bernilai tinggi. Bila dilihat dalam lingkup kawasan, Kota Lama mempunyai kelangkaan/ scarcity, karena Kota Lama merupakan kawasan yang utuh dan tersendiri, dengan bangunan-bangunan kuno bersejarah di dalamnya.

Bila dilihat sekarang, Kota Lama belum mempunyai manajemen atraksi yang baik. Semuanya dibiarkan saja apa adanya. Walaupun banyak potensi-potensi yang sudah dimasukkan dalam RTBL untuk diolah, namun RTBL tersebut terlalu berkesan 'mega project' sehingga selama ini pemerintah cenderung berdiam diri dengan alasan tidak ada biaya untuk mengelola dan mengkonservasi kawasan. RTBL tidak mencantumkan tahapan-tahapan pengelolaan, padahal di lain sisi mengkonservasi sebuah bangunan dan kawasannya dibutuhkan biaya yang besar, butuh investor yang besar, juga pioneer-pioneer untuk bergerak dalam bidang pariwisata. RTBL juga tidak merencanakan pengelolaan bangunan dan lingkungan berdasar faktor penggerak produk (product driven), sehingga tidak diketahui mana produk-produk yang nantinya akan masuk dalam kategori core product / tangible product / augmented product. Sebab, bila hal ini tidak dijadikan dasar perencanaan pengembangan akan menyebabkan tidak adanya prioritas dalam proses pengembangan.

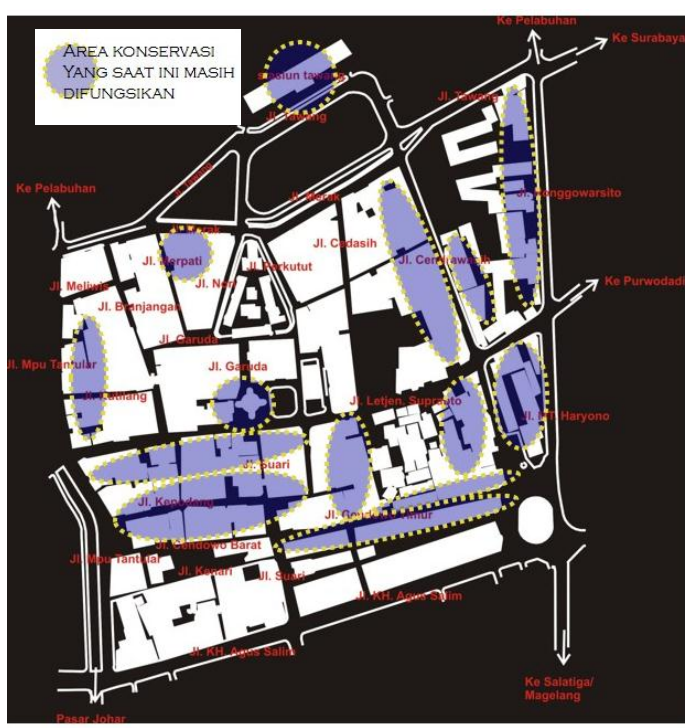

Gambar 5. Area Konservasi yang saat ini dipergunakan

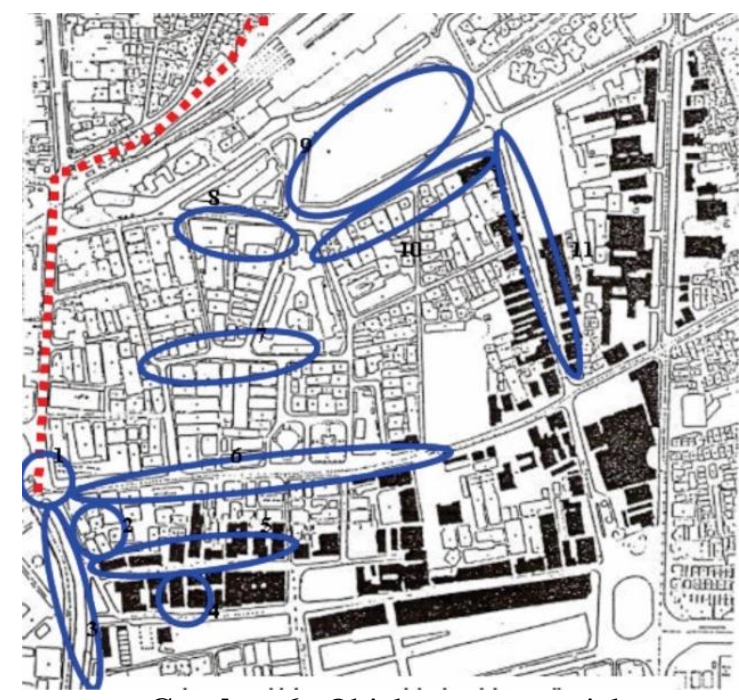

Gambar 6. Objek yang potensial mempunyai daya tarik

Kondisi ini dianggap penting, karena bila tidak ada skala prioritas maka pengembangan dan pengkonservasian sebuah kawasan cagar budaya akan sangat membutuhkan banyak biaya sekaligus. Hal ini dapat dikaji dari teori Kotler (1996) berikut ini:

- Core product, adalah produk utama yang 'dibeli' wisatawan, yang menghasilkan manfaat ketika kebutuhan wisatawan mampu dipenuhi oleh produk tersebut. Hal ini juga banyak dipengaruhi oleh hal-hal yang bersifat subjektif dan intangible, 
seperti suasana, pengalaman, dan kesenangan. Wisatawan melihat produk sebagai sebuah solusi terhadap masalah/kebutuhan mereka. Secara umum wisatawan membeli produk untuk memperoleh manfaatnya, dikarenakan atribut yang spesifik dari produk itu sendiri. Dilihat dari keterangan di atas, core product Kota Lama Semarang adalah bangunan kuno peninggalan jaman penjajahan Belanda. Namun saat ini, bangunan kuno di Kota Lama belum dimanfaatkan untuk mendukung pariwisata dan kondisinya banyak yang tidak terawat, terbengkalai dan kosong, bahkan beralih fungsi menjadi tempat prostitusi, permukiman liar, tempat menempel gubug-gubug gelandangan, dan tempat mangkal preman, sehingga pengalaman wisatawan tidak bisa optimal, bahkan cenderung minus. Aktifitas wisata di Kota Lama Semarang lebih berpusat di sekitar Gereja Blendug.

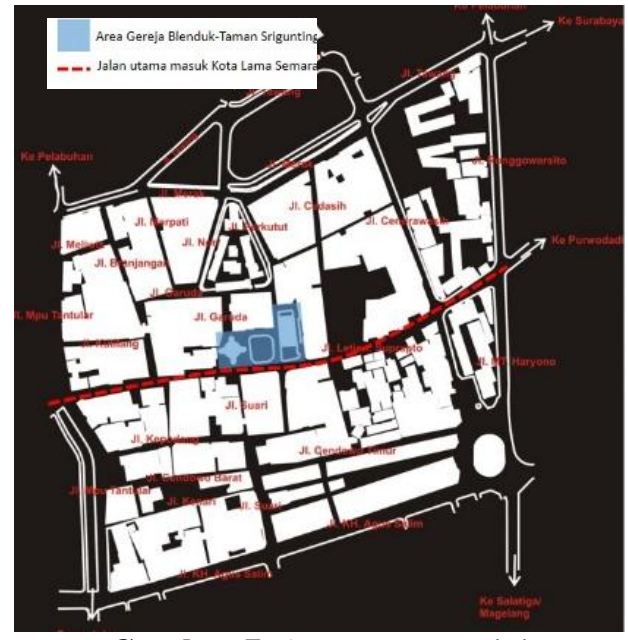

Gambar 7. Area yang saat ini menjadi pusat kegiatan wisata

Dari sekian banyak potensi di Kota Lama Semarang, hanya area Gereja Blendug dan Taman Srigunting yang sudah ada kegiatan wisata, seperti tata taman yang atraktif pada Taman Srigunting, adanya pasar seni, dan dimanfaatkannya bangunan sebagai café. Pada garis merah putus-putus adalah jalan utama memasuki kawasan Kota Lama Semarang, dimana sepanjang jalan tersebut banyak bangunan yang difungsikan sebagai perkantoran, dan beberapa café/minimarket. Dikarenakan kondisi bangunan yang masih sangat baik, area ini sudah memenuhi makna responsif dari pengunjung akibat suasana yang terbangun mampu mem-permainkan emosi/psikologis seseorang.

- Tangible product, adalah produk yang dibuat untuk mendukung core product, sehingga wisatawan akan merasa terpuaskan karena segala kebutuhannya terpenuhi. Tangible product ini mempunya lima karakter, yaitu: kelengkapan, brand name, kualitas, model, dan penyajian.

Kota Lama belum memiliki tangible product, baik itu dilihat dari kelima karakter, yaitu kelengkapan, brand, kualitas, model, dan penyajian. Bangunan kuno dan llingkungannya masih terkesan apa adanya (tidak ada pengelolaan), walaupun banyak bangunan-bangunan kuno tersebut dilihat dari sisi arsitekturalnya sangat berkualitas, namun karena tidak terawat dan tidak difungsikan sebagaimana mestinya, kualitasnya menjadi berkurang, sehingga brand image Kota Lama yang ada sekarang adalah sebuah kawasan kumuh, kurang aman, daerah rob, dan tempat prostitusi. Hanya sepanjang jl. Letjen Soeprapto yang 'seakan-akan' sudah terkelola, namun sebenarnya belum dikelola secara terpadu dalam sebuah link kepariwisataan. Gedunggedung tersebut terpelihara karena masih difungsikan.

- Augmented product, merupakan produk tambahan yang diberikan sebagai service dan manfaat yang diterima wisatawan dari tangible maupun intangible product.

Kota Lama saat ini sama sekali belum memenuhi augmented product, karena elemen kelengkapan kota, tourist information center, dan street furniture belum lengkap atau bahkan belum ada. Street furniture hanya ada di Taman Srigunting dan Taman Polder.

Dilihat dari kajian di atas, Kota Lama belum layak untuk dijual/dikatakan sebagai kawasan wisata (heritage), karena belum memenuhi kriteria sesuai dengan parameter dalam tingkatan produk, yaitu: kualitas produk (mempunyai aset yang potensial, namun belum berkualitas sebagai kawasan wisata, karena belum dikelola dengan baik), penampilan produk (masih apa adanya dengan keadaan yang kumuh, terbengkalai, kotor, dan tidak tertata), inovasi karakter produk (Kota Lama 
belum dikemas menjadi kawasan wisata yang menarik, yang mampu membentuk karakter yang bisa membedakan dengan kawasan lain).

Bila antara teori Attoe (1978) dalam Hollander (1980)dipadukan dengan teori Kotler (1996), tampak bahwa untuk membentuk suatu kawasan wisata heritage tidak hanya cukup dengan estetika, kejamakan, peranan sejarah, dan kemampuan memperkuat kawasan, namun perlu adanya pengelompokan produk wisata berdasar 3 (tiga) tingkatan produk yaitu kualitas, penampilan, dan inovasi karakter terhadap produk, sehingga Kota Lama mampu membentuk 'kelangkaan/scarcity' yang membedakan dengan kawasan lain.

\section{b. Aspek Elemen Penggerak Pariwisata}

Menurut teori Miossec (1977) dalam Afrodita (2012), untuk mengembangkan suatu kegiatan pariwisata di kawasan wisata terdapat stadium/fase yang dikaitkan dengan faktor pemicu perkembangan, yang juga merupakan faktor amenity (kelengkapan) seperti: resort/penginapan, transportasi, wisatawan, pengambil keputusan, dan masyarakat lokal.

- Kota Lama Semarang belum mempunyai penginapan yang berada di dalam kawasan. Penginapan-penginapan yang ada hanya disekitar/diluar Kota Lama Semarang. Bangunan-bangunan bersejarah yang ada di kawasan Kota Lama Semarang mestinya bisa di konservasi dengan infill design menjadi penginapan/hotel, sehingga atmosfer yang terbentuk bisa secara optimal berfungsi sebagai tempat wisata.

- Kota Lama Semarang sangat mudah diakses dengan transportasi umum. Apalagi dengan keberadaan stasiun Tawang yang merupakan bangunan heritage yang sangat tinggi nilainya. Kekurangannya adalah, di Kota Lama Semarang simpul-simpul jalan kurang nyaman untuk berwisata dikarenakan kesemrawutan lalu lintas, tidak adanya lahan parkir yang memadai, dan kurangnya infrastruktur kota yang berkaitan dengan street furniture.

- Kota Lama Semarang secara posisi, seperti wilayah yang berdiri sendiri dengan bangunan-bangunan kuno/heritage yang bernilai tinggi, sehingga membentuk atmosfer seakan-akan tidak berada di
Indonesia. Potensi ini sebenarnya cukup banyak menarik wisatawan yang ingin berkunjung. Apalagi Semarang secara berkala didatangi kapal pesiar dari Belanda (faktor kedekatan sejarah (memori). Selain itu, banyak wisatawan yang merupakan ilmuwan berkunjung ke Kota Lama Semarang untuk melakukan riset. Paling potensial adalah wisatawan dari Belanda karena ada keterkaitan emosi dengan Kota Lama Semarang.

- Sudah ada usaha dari pemerintah untuk menghidupkan Kota Lama Semarang, namun sifatnya masih sporadis, belum simultan, dan belum menyeluruh, sehingga masih banyak kawasan yang belum tergarap. Di beberapa tempat, seperti di sekitar Polder, di dalam gang-gang kecil, masih banyak terdapat bangunan-bangunan liar dan penghuni liar yang memberi kesan kumuh dan secara psikologis menimbulkan rasa kurang nyaman dan kurang aman. Pengawasan terhadap 'renovasi' bangunan juga banyak kurang sehingga muncul bangunan-bangunan yang menyalahi kaidah konservasi bangunan heritage.

- Masyarakat lokal dalam kawasan belum tergerak untuk mengambil peran. Banyak juga dari bangunan-bangunan tersebut yang dimiliki oleh orang yang tidak tinggal di Kota Lama, bahkan tidak tinggal di Semarang. Masyarakat seakan masih ragu untuk mengambil peran aktif, karena faktanya, mengkonservasi bangunan heritage memang membutuhkan biaya yang tidak sedikit, belum lagi aturan-aturan ketat yang mengikatnya.

\subsection{Kota Lama Semarang sebagai Attractive Urban Heritage}

Salah satu penjabaran atraktif adalah melalui metoda metafora. Metafora sebagai metode dalam mencapai tampilan atraktif berkaitan dengan makna arsitektural, yang sangat berpengaruh terhadap emosi (psikologi) pelaku/pengamat. Makna Arsitektural terdiri dari makna representasional dan makna responsif. Kedua hal tersebut akan dilihat dengan parameter Cullen (1964), dalam Benyon (2014), mengemukakan mengenai teori place, yaitu optic (orientasi), posisi (place), dan isi (content). Masih menurut Cullen (1964) 
dalam Benyon (2014), ciri khas sebuah kota adalah orientasi seri visual. Untuk melihat atau memahami setiap kawasan dalam sebuah kota dapat menggunakan metode ini. Evaluasi tampilan atraktif dalam Kota Lama Semarang menggunakan gabungan antara metode orientasi seri visual dan metafora.

Tabel 1. Analisis makna elemen produk wisata berdasar parameter atraktif dan teori place

\begin{tabular}{|c|c|c|c|}
\hline & $\begin{array}{l}\text { Optic } \\
\text { (Seri peman- } \\
\text { dangan yang } \\
\text { dinamakan } \\
\text { serial vision } \\
\text { (concerning } \\
\text { optics) }\end{array}$ & $\begin{array}{l}\text { Place } \\
\text { Reaksi } \\
\text { pengamat } \\
\text { terhadap } \\
\text { posisi } \\
\text { pengamat } \\
\text { dalam ling- } \\
\text { kungannya, } \\
\text { sehingga } \\
\text { diperoleh } \\
\text { situasi yang } \\
\text { dramatis. }\end{array}$ & $\begin{array}{l}\text { Content } \\
\text { Berkenaan } \\
\text { dengan } \\
\text { struktur } \\
\text { elemen kota } \\
\text { (fabric of } \\
\text { town), } \\
\text { seperti: skala, } \\
\text { tekstur, } \\
\text { karakter, } \\
\text { personalitas, } \\
\text { dan keunikan }\end{array}$ \\
\hline $\begin{array}{l}\text { Makna } \\
\text { Represen- } \\
\text { tasional } \\
\text { makna } \\
\text { presentasional } \\
\text { (ikon) dan } \\
\text { makna } \\
\text { referensional } \\
\text { (simbol) }\end{array}$ & $\begin{array}{l}\text { Hampir } \\
\text { seluruh } \\
\text { penggal- } \\
\text { penggal } \\
\text { jalan di Kota } \\
\text { Lama } \\
\text { mempunyai } \\
\text { potensi } \\
\text { yang besar. } \\
\text { Selain vista } \\
\text { dari } \\
\text { bangunan- } \\
\text { bangunan } \\
\text { kuno, juga } \\
\text { adanya } \\
\text { Pasar Ayam } \\
\text { di Jl. } \\
\text { Kepodang, } \\
\text { yang } \\
\text { apabila } \\
\text { ditata } \\
\text { dengan } \\
\text { lebih baik, } \\
\text { akan } \\
\text { semakin } \\
\text { menambah } \\
\text { nilai Kota } \\
\text { Lama } \\
\text { Semarang. } \\
\text { Kawasan ini } \\
\text { sebenarnya } \\
\text { akan } \\
\text { semakin } \\
\text { kuat } \\
\text { nilainya } \\
\text { apabila kita } \\
\text { menyusuri } \\
\text { jalan- } \\
\text { jalannya, } \\
\text { dimulai dari } \\
\text { jalan utama }\end{array}$ & $\begin{array}{l}\text { Terdapat } 3 \\
\text { (tiga) jalan } \\
\text { utama yaitu } \\
\text { Jl. Suprapto, } \\
\text { Jl.Mpu } \\
\text { Tantular, Jl. } \\
\text { Tawang } \\
\text { yang } \\
\text { mempunyai } \\
\text { karakter } \\
\text { jalan yang } \\
\text { panjang dan } \\
\text { lurus, dan } \\
\text { didukung } \\
\text { oleh jajaran } \\
\text { bangunan- } \\
\text { bangunan } \\
\text { kuno, } \\
\text { terutama di } \\
\text { Jl. Suprapto } \\
\text { dan Jl. Mpu } \\
\text { Tantular. } \\
\text { Jalan-jalan } \\
\text { tersebut } \\
\text { sangat } \\
\text { berpotensi } \\
\text { untuk di } \\
\text { konservasi } \\
\text { sehingga } \\
\text { menciptakan } \\
\text { serial view } \\
\text { yang sangat } \\
\text { menarik, dan } \\
\text { menciptakan } \\
\text { atmosfer } \\
\text { dramatis. }\end{array}$ & $\begin{array}{l}\text { Kota Lama } \\
\text { mempunyai } 2 \\
\text { (dua) ikon } \\
\text { yaitu Gereja } \\
\text { Blenduk dan } \\
\text { Stasiun } \\
\text { Tawang. } \\
\text { Bahkan } \\
\text { Gereja } \\
\text { Blenduk } \\
\text { merupakan } \\
\text { Landmark } \\
\text { Kota Lama. } \\
\text { Area di } \\
\text { sekitar } \\
\text { Gereja } \\
\text { Blenduk } \\
\text { inilah area } \\
\text { yang paling } \\
\text { ramai } \\
\text { kegiatan } \\
\text { wisata. Ikon } \\
\text { Kota Lama } \\
\text { lainnya } \\
\text { adalah } \\
\text { stasiun } \\
\text { Tawang. } \\
\text { Sama halnya } \\
\text { dengan } \\
\text { gereja } \\
\text { Blenduk- } \\
\text { Taman } \\
\text { Srigunting, } \\
\text { stasiun } \\
\text { Tawang } \\
\text { sebagai } \\
\text { simbol urban } \\
\text { heritage } \\
\text { rusak dengan } \\
\text { masih } \\
\text { adanya }\end{array}$ \\
\hline
\end{tabular}

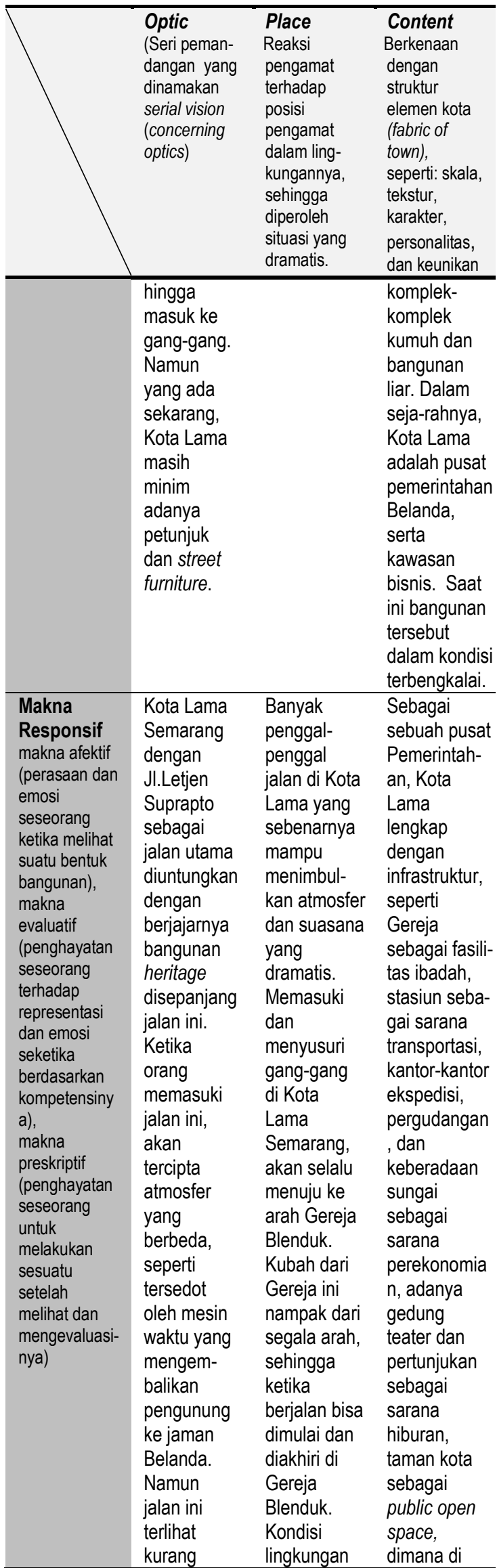




\begin{tabular}{lll}
\hline Optic & Place & Content \\
(Seri peman- & Reaksi & Berkenaan \\
dangan yang & pengamat & dengan \\
dinamakan & terhadap & struktur \\
serial vision & posisi & elemen kota \\
(concerning & pengamat & (fabric of \\
optics) & dalam ling- & town), \\
& kungannya, & seperti: skala, \\
& sehingga & tekstur, \\
& diperoleh & karakter, \\
& situasi yang & personalitas, \\
& dramatis. & dan keunikan \\
\hline tertata, tidak & sekitar & taman ini \\
adanya jalur & penggal & sering \\
pedestrian & jalan ini & diadakan \\
yang & belum cukup & festival dan \\
memadai, & mem-buat & karnaval, dan \\
tidak & nyaman & gedung- \\
adanya & pejalan kaki & gedung \\
peneduh, & dikarenakan & perkantoran, \\
membuat & kondisi & dimana saat \\
jalan ini & bangunan & itu semuanya \\
yang & yang banyak & merupakan \\
seharusnya & terbengkalai & sebuah \\
sebagai & dan tanpa & 'cerita' \\
jalan yang & kegiatan, & tentang kota, \\
bersifat & juga & dimana \\
'menyambut & terdapat & pemerintah \\
'akhirnya & hidden & Belanda \\
malah & space, & membangun \\
menimbulka & sehingga & gedung \\
n persepsi & tidak banyak & maupun \\
terhadap & wisatawan & jaringan kota \\
suatu & yang mau & yang \\
kawasan & melakukan & disesuaikan \\
yang & penyusuran & dengan \\
abandoned. & kota, apalagi & kondisi \\
& mempelajari- & topografi \\
& nya. & Semarang. \\
\hline & & \\
& & \\
& &
\end{tabular}

\section{KESIMPULAN}

\subsection{Aspek Produk Pariwisata}

Demand wisatawan terhadap Kota Lama Semarang adalah sebuah kawasan wisata sejarah yang memenuhi faktor-faktor estetika, kejamakan, kelangkaan, peranan sejarah, dan memperkuat kawasan, dan diperkuat dengan lingkungan yang mampu mendukung kegiatankegiatan pariwisata (keamanan, kenyamanan, kebersihan, keteraturan, dan kemudahan).

\subsection{Aspek Elemen Penggerak Pariwisata}

\section{a. Ekspektasi Tour Guide/Tour Operator dan Masyarakat}

Dalam mengembangkan kawasan wisata sejarah, tidak hanya dipengaruhi oleh faktor pemicu perkembangan (resort, transportasi, wisatawan sebagai pengambil keputusan, dan masyarakat lokal), tetapi juga harus dilengkapi dengan adanya jaminan keamanan dan kenyamanan (yang didukung dengan kelengkapan amenitas), serta adanya even/even untuk dinikmati, sehingga wisatawan mempunyai berbagai kegiatan untuk menghabiskan waktu. Hal inilah yang diharapkan tour operator/tour guide ada pada Kota Lama Semarang, sehingga dapat kembali memiliki nilai jual.

Masyarakat berharap pemerintah bersikap tegas dalam menangani masalah lingkungan di Kota Lama Semarang, dan menatanya dengan melibatkan masyarakat, tidak hanya sebatas sebagai pihak yang diikutkan dalam diskusi, namun juga pihak yang berperan aktif dalam pengelolaannya. Masyarakat juga berharap masalah rob ditangani dengan lebih serius, adanya aturan konservasi yang jelas dan disosialisasikan dengan baik agar pemilik bangunan mempunyai acuan yang jelas dalam mengelola bangunan miliknya, dan penanganan yang tegas terhadap preman.

\section{b. Faktor-Faktor Penyebab Stagnasi Kota Lama Semarang}

Pemerintah hanya berperan sebagai pembuat kebijakan, sedangkan perannya sebagai penyedia anggaran belum sepenuhnya dilaksanakan. Pola pikir Pemerintah masih dibentuk oleh anggapan bahwa kemajuan/ keuntungan ekonomi bisa diperoleh secara instan, sehinggan kurang memberi perhatian kepada hal-hal yang diperkirakan membutuhkan usaha dan perjalanan panjang untuk mencapai kesuksesan. Kebijakan Pemerintah dipengaruhi oleh faktor sosiopolitik, dimana pemerintah menganggap Kota Lama Semarang tidak memberikan keuntungan untuk aspek politik, sehingga pemerintah kurang memperhatikan pengelolaannya.

Partisipasi elemen-elemen dalam sosio-kultural belum terjalin dengan baik. Usaha-usaha yang dilakukan hanyalah sebatas mengadakan diskusi-diskusi, yang aplikasinya di lapangan belum tampak. Di sisi lain, pembicaraan/diskusi-diskusi tersebut belum mengikutsertakan semua unsur yang terkait dengan terpadu dan terkoordinasi dengan baik.

Pemerintah dan stakeholder Kota Semarang belum mampu menangkap peluang yang ada 
dengan kedatangan kapal pesiar setiap tahunnnya di pelabuhan Tanjung Mas. Peluang tersebut justru banyak dimanfaatkan oleh stakeholder dari luar Semarang, seperti tour operator dari Jogjakarta dan Jakarta.

Pemerintah belum mampu memandang Kota Lama Semarang sebagai aset yang dapat mendatangkan keuntungan yang mana hal ini dibuktikan dengan tidak adanya anggaran untuk merevitalisasi Kota Lama Semarang, maupun membangun elemen-elemen kelengkapan kota. Pemerintah terbukti belum mampu menjadikan kawasan agar mampu memenuhi demand wisatawan maupun masyarakat.

Pemerintah belum mampu/tidak melaksa-nakan manajemen kawasan wisata, sehingga wisatawan belum dapat menikmati lingkungan dan bangunan kuno dengan aman dan nyaman, baik itu aman dari kendaraan bermotor maupun dari kriminalitas, belum dapat merasakan kenyamanan saat berwisata yang diakibatkan dari asap dan lalu lalang kendaraan bermotor, terik matahari, polusi, dan belum ada tempat untuk beristirahat, makan dan minum. Wisatawan juga tidak mendapatkan kemudahan dalam memperoleh informasi tentang sejarah bangunan dan Kota Lama secara keseluruhan, sehingga wisatawan masih mengalami kesulitan saat melakukan tour keliling Kota Lama Semarang dan belum dapat mendalami sejarah/nilai penting bangunan kuno dan lingkungannya

\section{REKOMENDASI}

Perlu adanya pengembangan dan penerapan metode perencanaan yang dapat digunakan untuk mengembangkan Kota Lama Semarang sebagai kawasan wisata sejarah. Salah satu aspek yang perlu menjadi perhatian utama yaitu masalah konservasi bangunan dan lingkungan, dilihat dari faktor:

1. Estetika, berkaitan dengan nilai estetis dan arsitektural, meliputi: bentuk, struktur, ornamental, tetapi juga harus memperhatikan tata ruang.

2. Kejamakan, bentuk suatu ragam atau jenis khusus yang spesifik.

3. Peranan sejarah, berkaitan dengan bangunan yang memiliki nilai historis, tetapi juga harus memperhatikan lingkungan kota

4. Mengolah potensi-potensi yang ada dan mengemasnya agar mampu mempekuat kawasan, yang berkaitan dengan kehadiran suatu obyek, atau kehadiran suatu karya yang akan mempengaruhi kawasan-kawasan sekitar dan bermakna untuk meningkatkan kualitas dan citra lingkungan.

Selain rekomendasi di atas, rekomendasi lainnya adalah mengobservasi dan mengolah dengan sungguh-sungguh potensi yang ada di Kota Lama Semarang, termasuk di dalamnya adalah bangunan, lingkungan kota (berkaitan dengan elemen-elemen kelengkapan kota), juga sumber daya, untuk kemudian dimasukkan dalam empat tingkatan produk (core product, facilitating product, supporting product, dan augmented product), dengan memperhatikan kualitasnya, penampilannya, dan inovasi karakternya. Ini bertujuan agar Kota Lama Semarang dapat menjadi kawasan wisata sejarah yang mempunyai 'jiwa' dan kegiatan/even yang sesuai dengan karakter kawasan, sehingga tidak lagi menjadi kota mati, dan experience wisatawan dapat tercapai dengan optimal.

Diperlukan keseriusan dari pemerintah untuk menggerakkan stakeholder lokal sehingga mampu lebih berperan dalam mengembangkan Kota Lama Semarang sebagai kawasan wisata sejarah. Keseriusan pemerintah tersebut dapat ditunjukkan dengan pengadaan alokasi dana anggaran untuk membangun/mengembangkan/ mengelola Kota Lama Semarang, dan mengkoordinasi secara terpadu elemen-elemen sumber daya manusia, termasuk instansi pemerintah, pakar-pakar/profesional terkait, dan masyarakat setempat mapun sekitar.

\section{DAFTAR PUSTAKA}

........ 1981. The Burra Charter for The Conservation of Place of Cultural Significance, p. 2

Afrodita, Borma. 2012. Models of Tourist Development in the Context of Regional Development. Volume 2012 Number 01 Issue No.1. July 2012.

Antoniades, Anthony C. 1990. Poetics of Architecture. New York: Van. Nostrand Reinhold.

Benyon, David. 2014. Spaces of Interaction, Places for Experience. Morgan and Claypool Publishers series. Penn State 
University

Dinas Pekerjaan Umum Kota Semarang. 2017.

Laporan Akhir RTBL Kota Lama

Semarang.

Hess, Renata Heryawati dan Saptorini, Hastuti.

2007. Karakter Atraktif dalam

Perancangan Taman Petualangan Anak.

Dimensi, Journal of Architecture and Built

Environment. Vol. 35, No.1. Program

Studi Arsitektur, Universitas Petra, Surabaya.

Hollander, Michael. 1980. Review: Architecture and Ciritical Imagination by Wayne Attoe. Journal of the Society of Architectural Historians Vol. 39 No. 2, May, 1980. The University of California Press.

Inskeep, Edward. 1991. Tourism Planning: An Integrated and Sustainable Development Approach. Van Nostrand Reinhold, New York.

Kotler, Philip., Bowen, John, And Makens, James. 1996. Marketing For Hospitality and Tourism. Prentice Hall, Upper Saddle River.

Larkham, Peter J. 1995. Heritage as Planed and Conserved: Heritage, Tourism, and Society. Manshel Publishing Ltd, USA

Nuryanti, Wiendu. 1996. Heritage And Postmodern Tourism. Elsevier Science Ltd

Yuliasari, Indah. 2017. Pelestarian dan Penataan Bangunan Kota (Urban Heritage) di Kabupaten Magelang. Prosiding Seminar Heritage IPLBI 2017.

Wallpaper Foto Semarang Tempo Dulu. http://seputarsemarang.com/wallpaperfoto-semarang-tempo-dulu/, diakses 20 April 2018. 